Article

\title{
The Artist's Book in the Age of Digital Reproduction: Walter Benjamin and the Artist's Book
}

\author{
Stephen Bury \\ The Frick Art Reference Library, New York, NY 10021, USA; bury@frick.org \\ Received: 11 September 2019; Accepted: 18 October 2019; Published: 21 October 2019
}

\begin{abstract}
Walter Benjamin, who was familiar with the pre-Second World War avant-garde, argued that mechanization threatens the aura of art objects. The digital revolution has been seen as reconfirming Benjamin's thesis, but the digital can be seen to reaffirm the value of the actual, physical artist's book, and moreover, artists have exploited the digital — as technologies and subject matter-to make artists' books.
\end{abstract}

Keywords: avant-garde; mechanization; aura; artists' books

Walter Benjamin's The Work of Art in the Age of Mechanical Reproduction (1936, the "Third version"), published in Illuminations (1968) (Benjamin 1992), has a grand historical sweep: against a background of the development of capitalism and the emergence of reproductive techniques, such as lithography and photography, followed by the invention of film and sound film in particular, Benjamin argues for a diminution and even elimination of the aura-the authenticity of the artwork, which he defines thus:

The authenticity of a thing is the quintessence of all that is transmissible in it from its origin on, ranging from its physical duration to the historical testimony relating to it. (Benjamin 2002, p. 103)

Benjamin's antiheroes include two figures important for the history of artists' books-Stéphane Mallarmé (1842-1898), whose Un coup de dés jamais n'abolira le hazard (1897) transformed how space and text could work across verso and recto, and Filippo Tommaso Marinetti (1876-1944), whose parole in liberta (words in freedom), in a different way from Guillaume Apollinaire's calligrammes, made text into image. Benjamin sees Mallarmé attempting to preserve Renaissance notions of beauty:

This ... gave rise to a negative theology, in the form of an idea of "pure art", which rejects not only any social function but any definition in terms of representational content. (In poetry, Mallarmé was the first to adopt this standpoint.) (Benjamin 2002, p. 106)

Marinetti haunts the last section of Benjamin's text. He accuses the futurist Marinetti of aestheticizing politics in the service of fascism.

Dadaism (and, to a much lesser extent, surrealism) also features in the essay. Benjamin sees Dadaism as an abortive realization of the effect of mechanical reproduction on aura. Although criticizing it for "barbarism", Benjamin sees Dadaism as attempting to "produce with the means of painting (or literature) the effects which the public today seeks in film" (Benjamin 2002, p. 118):

Their poems are "word salad" containing obscene expressions and every imaginable kind of linguistic refuse. The same is true of their paintings, on which they mounted buttons or train tickets. What they achieved by such means was a ruthless annihilation of the aura in every object they produced, which they branded as a reproduction through the very means of its production. (Benjamin 2002, p. 119) 
Benjamin was well acquainted with the avant-garde. He wrote about surrealism; knew André Breton (1896-1966); translated a Tristan Tzara (1896-1963) essay for Hans Richter's G magazine, issue 3 (June 1924); and had met Marcel Duchamp in 1937, who had given up retinal painting by 1918: in a Boulevard St. Germain café, Duchamp showed him a hand-colored pochoir of his painting Nude Descending a Staircase (1912) from his Box in Valise, and Benjamin described it as "breathtakingly beautiful" (Benjamin 1999a, pp. 207-21; Bury 2013, p. 865; Bury 2017, pp. 111-12).

The pre-1937 avant-garde liked to use print—-the 2007 exhibition 'Breaking the Rules' at the British Library looked at their use of the printed manifesto, magazine, the livre d'artiste, artist's books, and photobook as opposed to painting and sculpture (Bury 2007). Jedermann sein eigner Fussball (Everyman his own football), dated 15 February 1919, and costing 30 pfennigs, took the format of a newspaper. Although the edition was large-7600_-that number included a limited edition of 100, of which the first 20 were signed and numbered. Very few copies have survived. Zurich Dada magazines likewise had deluxe copies. Alfred Stieglitz's 291 (1915-16) even had some copies on vellum. The surrealist bookseller José Corti's 1930 catalogue offered a wide range of versions: Breton's Seconde Manifeste du Surrealisme was also available in an edition of 60 copies sur vélin annam de Rives; Aragon's Le Paysan de Paris (1926), a formative influence on Benjamin's Der Passagen Werk/Arcades Project, had a numbered as well as an ordinary edition (Corti 1930). Even with the avant-garde's embrace of mechanical reproduction, there were many exceptions to the general rule, and semi-unique copies were often privileged.

It is impossible to speculate what Benjamin would have made of the digital revolution: he would probably have argued that it offers prospects for socialism but also fascism. However, does the digital revolution have a similar impact on aura as did the mechanical revolution?

The development of personal computers in the 1970s began to give access to online information that otherwise was confined to expensive printed encyclopedias on monographs. From 1985 onwards, CD-ROMs amplified this impact. At the same time, desktop publishing programs (DTP) developed, although the first 1984 Macintosh did not have such a capacity. Self-publishers could now design and manipulate text and images to make their own publications from civic newspapers to artists' books: the great zines movement of the 1990s to the present was also made possible.

The book was freed up from the responsibility of being the main channel of communication of information. This reopened the book format: the sequence of pages; the juxtaposition of image and text, image and image, and text and text; a private space that could also be public; the relationship of author and reader (and the question of who was who); and the ergonomics of size, weight, texture, and even smell (Bury 1995, pp. 1-5). Michael Snow's Cover to Cover (1975) could be made with a DTP program and put up on the internet, but the handling requisite to understand and follow its play with recto and verso requires physical manipulation. This is also the case with Yoko Terauchi's Ebb E Flow (1988) - a sheet of paper painted red on one side and blue on the other, with a tear that allows reverse color to show through as each page is turned (Bury 2015, p. 18). It would be impossible to do this digitally. Take also the case of Susan Hiller's Rough Sea (1976): it would be easy to scan the postcards of South Coast, England, and rough seas and put them up online, but as you turn the pages of the printed book, you get a cut-a memory continuity-but also abrupt changes, as if the seas are pounding in and then retreating, dragging, and sucking back the shingle and seaweed.

The digital revolution offered a set of tools that artists could use-digital photography and diffusion via the internet (e.g., Giles Lane's diffusion.org.uk 2003-9 or the Espresso Book Machine 2006-) as well as the programming of text. A text engine is "a device or machine, which generates new text or reprocesses existing text into new text through the application of a rule or series of rules or algorithms" (Bury 2010, p. 10). This idea existed before the digital age-Jonathan Swift's "Voyage to Laputa" has an Academician demonstrating a physical sentence compiler with handles. Likewise, Georges Perec (1936-1982), a member of OULIPO (Ouvroir de littérature potentielle or Workshop for Potential Literature), excluded the letter ' $\mathrm{e}$ ' in La disparition (1969) manually. 
As the collective Information as Material, Simon Morris, Nick Thurston, and Derek Beaulieu have manipulated existing texts-Freud, Blanchot, or Abbott (all authors on the avant-garde reading list) - using computer programming. They have also published Sarah Jacobs, whose own press is called Colebrooke Publications 1996-. In 2002, she published The Unknown Masterpiece Drawing Book, putting another avant-garde classic, Balzac's Le chef d'oeuvre inconnu, through a Linguisti-Go (Mark 11) translation program repeatedly until the text was destabilized and unreadable. Her most recent book, An Accumulation of Fictions (2018), involved the scanning of 384 volumes of novels, putting them in spreadsheets and running text from each volume through "an algorithm which was intended to ensure that I was not just picking out favourite bits, or suppressing parts I did not like."

The internet, a central part-at least for now-of the digital revolution can also provide subject matter. Susan Hiller (1940-2019), whose Rough Seas has already been discussed, published Auras/Levitations for Book Works in 2008. It is small, $4.3^{\prime \prime} \times 3^{\prime \prime}$ and, thus, fits naturally into the palm of a hand. It contains two books in a tete-beche format, starting at each end, meeting in the middle with both colophons, and requiring a flip of the book to "read" the other. Auras: Homage to Marcel Duchamp references Duchamp's retinal painting, the 1910 portrait of his friend and future doctor Raymond Dumouchel, who was training as a radiologist at the time. The image was included in Duchamp's Box in Valise and is now part of the Arensberg Collection in the Philadelphia Museum of Art. Influenced by fauvism and Van Dongen in particular, Duchamp gives Dumouchel's hands an aura or "halo" in Duchamp's terms. Hiller plays with this, looking for portraits on the internet with "auras". She uses 35 found color photographs - the index, list of contents, or whatever we want to call this part of the book is a listing of internet locations of the images. In her introduction, Hiller sees the aura portraits "as metaphors for the self in our contemporary age" but also references Walter Benjamin. The point of departure for the second book/second part of the book is Yves Klein's photograph Leap into the Void (1960). This time Hiller collected 35 black-and-white images of levitation. Likewise, the work concludes with a list of internet pages-interestingly, in 2019, nearly all of these and those for Aura have disappeared, suggesting the fugitiveness and fragility of unarchived internet content.

Kenneth Goldsmith's Capital: New York Capital of the 20th Century (2015), with its gold binding and case, is an impressive 1002-page tome, simulating an oversized gold bar, although Wall Street's capitalism is more to do with credit, risk, and hedges than with bullion. Goldsmith, who at times describes his work as "uncreative writing", is parodying, glossing, supporting, or undermining Walter Benjamin's uncompleted project Das Passagen-Werk or The Arcades Project (Benjamin 1999b). Benjamin's project began in 1927 based on the Parisian arcades or passages. Worked on from 1928 to 1929 and then again from 1934 to 1940, it was influenced by surrealism and particularly the Dadaist/Surrealist Aragon. This soon developed into a history of the 19th century and increasingly concentrated on the poet Charles Baudelaire (1821-1867) but was left unfinished-one theory has it that Benjamin was carrying a more finished version in his suitcase before his suicide in 1940, facing possible expulsion back to France from Portbou. In Paris, he had left behind 426 loose-folded sheets in 36 sheafs or Konvolut or convolutes. There are cross-references, denoted by squares and other symbols, crosses, and circles in several colors-almost prescient of the 2010s notebook/journal movement. They were revised and composed concurrently (Benjamin 1999b, p. 958). Benjamin's topics are wide ranging: arcades (Passage du Caire, Choiseul, Colbert, Commerce-Saint-André, de l'Opera, des Deux Pavillons, de Panoramas, Vélo-Dodat, Viollet, Vivienne), sales clerks, fashion, catacombs, boredom, Haussmannization, iron construction, advertising, Grandville, Baudelaire, flaneur, prostitution, gambling, panorama, mirrors, railroads, Fourier, Marx, photography, dolls, stock exchange, the Commune, Seine, idleness, etc. Goldsmith's 52 categories are similar and different: panorama, flaneur, advertising, art, and glass mirror Benjamin's categories_as does the New York urban planner Robert Moses, echoing the Parisian Baron Haussmann. Others do not: Coney Island, Central Park (although a Zentral Park does appear in Benjamin's work), Mapplethorpe, subway, 1939 and 1964 World Fairs, World Trade Center, etc. Goldsmith's source material is as wide and eclectic as Benjamin's. Goldsmith begins with Woody Allen's writer character at the opening of his film Manhattan (1979), repeating his beginnings of his 
chapter one: "He adored New York City ... He was too romantic about Manhattan ... ". However, there are emails, government documents, extracts from novels, etc. Its prepublication twitter feed was printed in Convolution 3, echoing Benjamin's Konvolut and emphasizing that the play between digital and analogue is not a one-way street.

Funding: This research received no external funding.

Conflicts of Interest: The author declares no conflict of interest.

\section{References}

Benjamin, Walter. 1992. Illuminations. London: Fontana Press.

Benjamin, Walter. 1999a. Surrealism: the last snapshot of the European intelligentsia. In Selected Writings: Volume 2 1927-1934. Cambridge: Belknap Press of Harvard University Press.

Benjamin, Walter. 1999b. The Arcades Project. Cambridge: Belknap Press of Harvard University Press.

Benjamin, Walter. 2002. The Work of art in the age of technological reproducibility, Second Version. In Selected Writings: Volume 3 1935-1938. Cambridge: Belknap Press of Harvard University Press.

Bury, Stephen. 1995. Artists'Books: The Book as a Work of Art, 1963-1995. Aldershot: Scolar Press.

Bury, Stephen. 2007. Breaking the Rules: The Printed Face of the Avant Garde 1900-1937. London: British Library.

Bury, Stephen. 2010. The Text engine and the artist's book. In At the Turn of the Centuries: The Influence of Early 20th Century Book Arts on Contemporary Artists' Books. New Haven: Jenny-Press.

Bury, Stephen. 2013. “Not to adorn life but to organize it": Veshch. Gegenstand. Objet: Revue international de l'art modern (1922) and G (1923-6). In The Oxford Critical and Cultural History of Modernist Magazines: Volume III, Europe 1880-1940, Part II. Edited by Peter Brooker, Sascha Bru, Andrew Thacker and Christian Weikop. Oxford: Oxford University Press.

Bury, Stephen. 2015. Artists' Books: The Book as a Work of Art, 1963-2000. London: Quaritch.

Bury, Stephen. 2017. Marcel Duchamp's Boite-en-valise. Print Quarterly 34: 111-12.

Corti, José. 1930. Le Groupe Surréaliste: Catalogue de Livres en Vente. Paris: Librairie José Corti.

(C) 2019 by the author. Licensee MDPI, Basel, Switzerland. This article is an open access article distributed under the terms and conditions of the Creative Commons Attribution (CC BY) license (http://creativecommons.org/licenses/by/4.0/). 